Schweiz. Z. Path. Bakt. 1940;3:I-VIII

\title{
Contents, Vol. 3, 1940
}

Schweizerische Zeitschrift

fur

\section{ALLGEMEINE PATHOLOGIE UND BAKTERIOLOGIE}

Revue Suisse de Pathologie générale et de Bactériologie

Unter ständiger Mitarbeit zahlreicher Fachgelebxter herausgegebe $\pi$ von

A. v. Albertini - A. Grumbach - H. Mooser Zurich

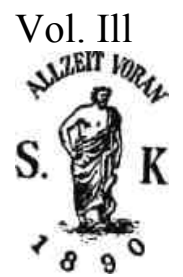
BASEL (Schweiz)
S. K A R G E R
NEW YORK
Holbcin t traßse 22
215 Fourth Avenue

For USA.: Nord $\beta$ maa Publishing, Inc., Dept. S. Karger, 215 Forth Avenue, New York, N. Y. Alle Rechte vorbehalten

Printed in Switzerland. Uruck von Friedrich Reinhardt in Basel.

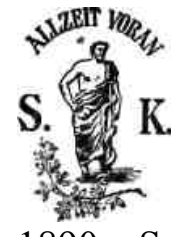

1890 S. KARGER 1940

VERLAG FÜR MEDIZIN UND NATURWISSENSCHAГTEN

A

m 1. April 1940 sind 50 Jahre seit der Gründung des medizinischen . Verlages S. KaГgeГ vergangen.

Herr S. Karger hatte zunächst die Absicht, für Ärzíe und Studierende kurze, von anerkannten Forschern verfaßte Anleitungen herauszugeben, um durch sie die für die Praxis notwendigen wissenschafdichen Grund-lagen und Erkenntnisse dem Lernenden auf möglichst hohem Niveau zu vermitteln. Nach dem vollen Eríolg dieser Bücher wurde schon von 1894 an a·ucL eine Reihe von Zeitschriften geschaffen, die eine Stellung zwischen den rein wissenschafdichen Archiven und den vorwiegend für die Praxis bestimmten Blättern einnehmen sollten. Diese Zeitschriften führten sich bald auf der ganzen Welt ein und nahmen an Zahl zu, so daß die persön-liche Initiative von Herrn S. Karger auch hier einen vollen Erfolg feiern durfie. Seit seinem Tode im Jahr 1935 wird der Verlag im Sinne des Grün-ders fortgeführt. Im Jahre 1937 erfolgte die Übersiedelung der Firma nach Basel. Hier wurde mit Hilfe der unterzeichneten Herausgeber die Verwirklichung der Idee weiterverfolgt, in den Zeitschriften 
eine Art Zentralstelle für eine internationale Zusammenarbeit auf den medizinischen Spezialgebieten zu schaffen. Die Zeitschriften sollten einem fordaufenden Gedankenaustausch dienen, etwa in der Art, wie er durch die internationalen Kongresse er-möglicht wird.

Es ist die Überzeugung des Verlages und der Herausgeber, daß eine solche Zusammenarbeit auf breitester internatíonaler Basis heute wichtiger ist als je. Deshalb wurde nicht nur den alien Zeitschriften eine neue Form

gegeben, sondern es wurden auch neue derartige internationale Organe ge-gründet. Sie haben sich trotz der ungünstigen äußeren Umstände schon in kurzer Zeit sehr gut eingeführt; es dürften zahlreiche persönliche Zustim-mungen, die von Forschern der ganzen Welt einlaufen, wohl ein Zeichen dafiir sein, daß wir urns hier auf dem richtigen Wege befinden.

Den unterzeichneten Herausgebern ist es ein Bedürfnis, dem Verlag S. Karger anläßlich seines 50jährigen Bestehens für das trotz der schweren Zeiten stets verständnisvoUe Eingehen auf ihre Wünsche zu danken und der Hoffnung Ausdruck zu geben, es möge den Bestrebungen des Verlags auch weiterhin ein voller Erfolg beschieden sein.

\section{$\mathrm{O}$}

$\mathrm{n}$ the 1st of April 1940, the Medical Publishing House, S. Karger will celebrate its 50th anniversary. The Founder, Mr. S. Karger originally intended to publish short textbooks for medical practitioners and students written by eminent scientists, in order to furnish the learner with the scientific fundamentals and knowledge necessary for practice. After these books had attained a full measure of success, a series of scientific journals were founded in 1894 intended to have an intermediate position between the purely scientific archives and the journals devoted to the practice of medicine. These soon spread throughout the whole world and increased in number, so that the personal initiative of Mr. S. Karger was rewarded with success.

Since his death in 1935, the Publishing House has been continued on the principles of its Founder.

In the year 1937, the Company moved to Basle. With the assistance of the undersigned Editors the idea was carried still further forward to make the journals a sort of central organ for international cooperation in the domain of medical specialities. The journals are meant to serve as a channel for the continuous exchange of ideas in a manner similar to that made possible by the International Congresses.

The Publishers and Editors are convinced that such cooperation on a wide international basis is more than ever essential today. Therefore, not only were the old journals given a new form, but new international organs have been called into being as well. In spite of the unfavourable circumstances obtaining, these periodicals made their way in a short space of time and the many personal acknowledgements received from scientists all over the world may well be proof that we are on the right road.

The undersigned Editors feel themselves constrained to offer the Publishing House S. Karger, on the occasion of the 50th anniversary of the foundation thereof, their sincerest thanks for the sympathetic favour ever accorded to their wishes and to express the hope that in ,spite of very difficult times the Firm's endeavours may also in the future meet with a full measure of success.

L

a maison d'éditions médicales S. Karger fêtera le ler avril 1940 le I cinquantième anniversaire de sa fondation. 
Après avoir publié, au debut et avec succès, une série de precis scien-tifiques destines aux praticiens et qui connurent et connaissent encore une très large diffusion, S. Karger lança, dès 1894, plusieurs périodiques médicaux qui ne tardèrent pas à se répandre dans tous les pays. Après la mort, survenue en 1935, du fondateur de la Maison, et fidèle à Гesprit qui Гavait animé, son successeur fut amené, en 1937, à se fixer à Bale, pour y établir, avec Гaide de divers rédacteurs, un centre de collaboration médicale internaüonale qui se révèle plus nécessaire aujourd'hui que jamais. A la liste des anciens périodiques transformés s'en ajouta de nouveaux; les uns et les autres se réjouissent d'un cercle de collaborateurs et de lecteurs de plus en plus étendu.

Les rédacteurs soussignés apportent ici à un éditeur sans cesse pré-occupé de ,servir” Гhommage de leur felicitations et de leur gratitude.

ANNALES PAEDIATRICI

(Jahrbuch für Kinderheilkunde)

(Fund. 1857) E. Freudenberg

DERMATOLOGICA

(Dermatologische Zeitschrift)

(Fund. 1893) W. Lutz

Monatsschrift für

GEBURTSHILFE UND GYNÄKOLOGIE

(Fund. 1894) E. Anderes, Th. Roller

GASTROENTEROLOGIA

(Archiv für Verdauungski ·ankheiten)

(Fund. 1895) A. Hurst, R. Staehelin

Monatsschrift für

PSYCHIATHIE UND NEUROLOGIE

(Fund. 1897) J. Klaesi

OPHTHALMOLOGICA

(Zeitschrift für Augenheilkunde)

(Fund. 1899) A. Bruckner, H. Weve

PRACTICA

OTO-RH1NO-LARYNGOLOGICA

(Fund. 1907) J. Berberich, E. Schlittler

RADIOLOGIA CLINICA

(Radiologische Rundschau)

(Fund. 1932) M. Lüdin

CARDIOLOGIA (Fund. 1937) B. Kisch, W. Löffler

BIO-MORPHOSIS (Fund. 1938) H. Bluntschli

CONFINIA NEUROLOGICA (Fund. 1938) E. A. Spiegel

Schweizerische Zeitschrift für

ALLGEMEINE PATHOLOGIE UND

BAKTERIOLOGIE

(Fund. 1938)

A. v. Albertini, A. Grumbach, H. Mooser

INDEX

Beeuwkes, H., Ueber eine Viruskrankheit des Meerschwein-

chens 65 
Bloch-Springer, Ch., Beitrag zur Frage der intrakraniellen Teratome 125

Braun, H., und W. Silberstei $\pi$, Zur Vereinfachung der Diagnostik pathogener Darmbakterien 189

- und /. von Vásárhelyi, Bestehen Unterschiede zwischen begeißelten und geißellosen Proteusbazillen in oxydierenden und reduzierenden Fermentfunktionen, und können letztere durch Antikörper und Antiseptika beeinträchtigt werden? 84

Cocchi, U., Zur Frage der echten Multiplizität maligner Primärgeschwülste 270

Dubois-Ferríère, H., Gyphose du clivus consecutive à la localisation cranienne de la Maladie de Paget . . 22

Kallós, P.\} und L. Kallós-Deffner, Karzinomstudien I. Experimentelle Beiträge zur Frage der Unempfänglichkeit der Milz für Karzinom 11

II. Stoffwechseluntersuchungen 75

Die «akute Milzschwellung» 141

Weitere Beiträge zur Frage der Unempfänglich-

keit der Milz für Karzinom 149

Kallós-Deffner, L., vide Kallós, P.

Maier, G., Ueber die Geschwulst-Metastasen durch retrograden Lymphtransport, besonders bei Darmschleimhaut-Metastasen 106

Mooser, H., Ueber die Beziehungen des murinen Fleckfiebers zum klassischen Fleckfieber 318

Oppíkofer, K., Zwei Fälle von Reticulosarkom des Knochenmarkes (Ewing-Sarkom) 200

Ottensooser, F., Ueber die Trübungsreaktion zwischen Perfringenstoxin und Menschenserum 168

Regamey, R., Résultats sérologiques chez les soldats suisses vaccines $\operatorname{con}^{1} / 8 \mathrm{e}$ le Typhus-Paratyphus-Tétanos (T.P.T.) 304 Rüedí, J., Zur Kenntnis des mikrozytenreichen Rundzellensarkoms $\quad 38$

Scheidegger, S., Fleckpankreas. Beitrag zur Entstehung der Fleckorgane 1

Silberstein, W., vide Braun, $\mathrm{H}$.

Suter-Burger, R., Eine neue Methode zur Darstellung der Markscheiden am Gefrierschnitt 56

Vásárhelyi, J. von, B.C.G.-Schutzimpfung bei Tieren verschiedenen Alters 161

Vásárhelyi, J. von, vide Braun, H.

Voldet, G., Etude anatomique et expérimentale de la Maladie de Besnier-Bæck du Poumon 
Wohlwill, F., Nachtrag zu der Mitteilung über «Hepatitis interstitialis infiltrativa diffusa» in dieser Zeitschrift,

Bd. II, p. 24061

BUCHBESPRECHUNGEN - BOOKS REVIEW - L1VRES NOUVEAUX

Bordet, Jules, Traité de $\Gamma$ lmmunité dans les Maladies In-

fectieuses $\quad 323$

Bruun, E., Experimental Investigations in Serum Allergy . 123

Radnót, M., Die pathologische Histologie der Tränendrüse 188

Vogelsang, Th. M., Séro-Diagnostic de la Syphilis . . 323 